\title{
Relations between migration, reproduction and nutrition in yellowfin bream Acanthopagrus australis
}

\author{
B. R. Pollock \\ Fisheries Research Branch, Department of Primary Industries, Comalco House, Brisbane, Queensland, Australia
}

\begin{abstract}
The yellowfin bream Acanthopagrus australis (Günther) is an estuarine species in which a large proportion of the adult population does not participate in the annual seaward spawning migration. Monthly samples of migratory and non-migratory yellowfin bream were collected from March to October 1982. Measures of gonad and oocyte development and 3 indices of nutritional state (feeding index, visceral fat index and condition factor) were obtained for each fish sampled. Gonads developed to a similar size in migratory and non-migratory adults. Successful reproduction, as indicated by the presence of hyaline-stage oocytes, only occurred in migratory fish. In non-migratory females oocytes developed to the yolk-stage, but then became atretic and were resorbed. In both groups stored energy reserves decreased as the gonads increased in size; however the rate of decrease was greater in migratory fish. Feeding almost ceased in migratory fish during the spawning period (May to Aug) because suitable food items (benthic animals and plants) are uncommon in the spawning areas. In non-migratory fish, feeding was reduced during the late spawning period, possibly because abundant energy reserves were available due to oocyte resorption. An examination of sex ratios within age classes indicated a decreasing tendency of females to participate in the spawning migration with age. All male fish older than age II participate in the spawning migration. The seasonal patterns of gonad development and nutritional state associated with the spawning migration of yellowfin bream are similar to those reported for other teleost fishes. These patterns have not been documented for the non-migratory component of other teleosts which have annual spawning migrations.
\end{abstract}

\section{INTRODUCTION}

The annual spawning migration is an integral part of the life-history of many teleost fishes. However there is much interspecific variability in spawning migrations (Harden Jones, 1968), as exemplified by the migrations of anadromous fishes (e.g. salmon, shad, sea-lampreys) which spend most of their lives in the sea and migrate to freshwater to spawn, and of catadromous fishes (e.g. freshwater eels) which spend most of their lives in freshwater and migrate to the sea to spawn. Many estuarine fishes in the Indo-Pacific region undergo an annual migration in which adults move to the sea to spawn (Day et al., 1981); one such species is the yellowfin bream Acanthopagrus australis (Günther) (Pollock, 1982a). Juvenile and adult yellowfin bream inhabit estuarine areas (Blaber and Blaber, 1980). During the spawning period (May to Aug; Pollock, 1982b) adults migrate in large numbers to areas near surf bars (i.e. the junction of estuary and ocean). The spent adults return to estuarine areas after the spawning period (Pollock, 1982a). The planktonic larval stages of yellowfin bream are abundant at surf bars after the spawning period (Pollock et al., 1983).

Changes which occur in the nutritional state of fishes during annual spawning migrations have been reported in several studies (Greene, 1926; Idler and Clemens, 1959; Leggett and Trump, 1978). Feeding rates and stored energy reserves decrease and there is an increase in gonad development associated with annual spawning migrations. It is interesting to note that in several species which have annual spawning migrations, a large proportion of the adult population does not take part in the migration each year. In the Indo-Pacific region the phenomenon has been recorded in mullet Mugil cephalus by Thomson (1955); Pacific salmon Oncorhynchus spp. by Harden Jones (1968); various estuarine fishes in southern Africa by Wallace (1975); and barramundi Lates calcarifer by Moore and Reynolds (1982). In yellowfin bream, 


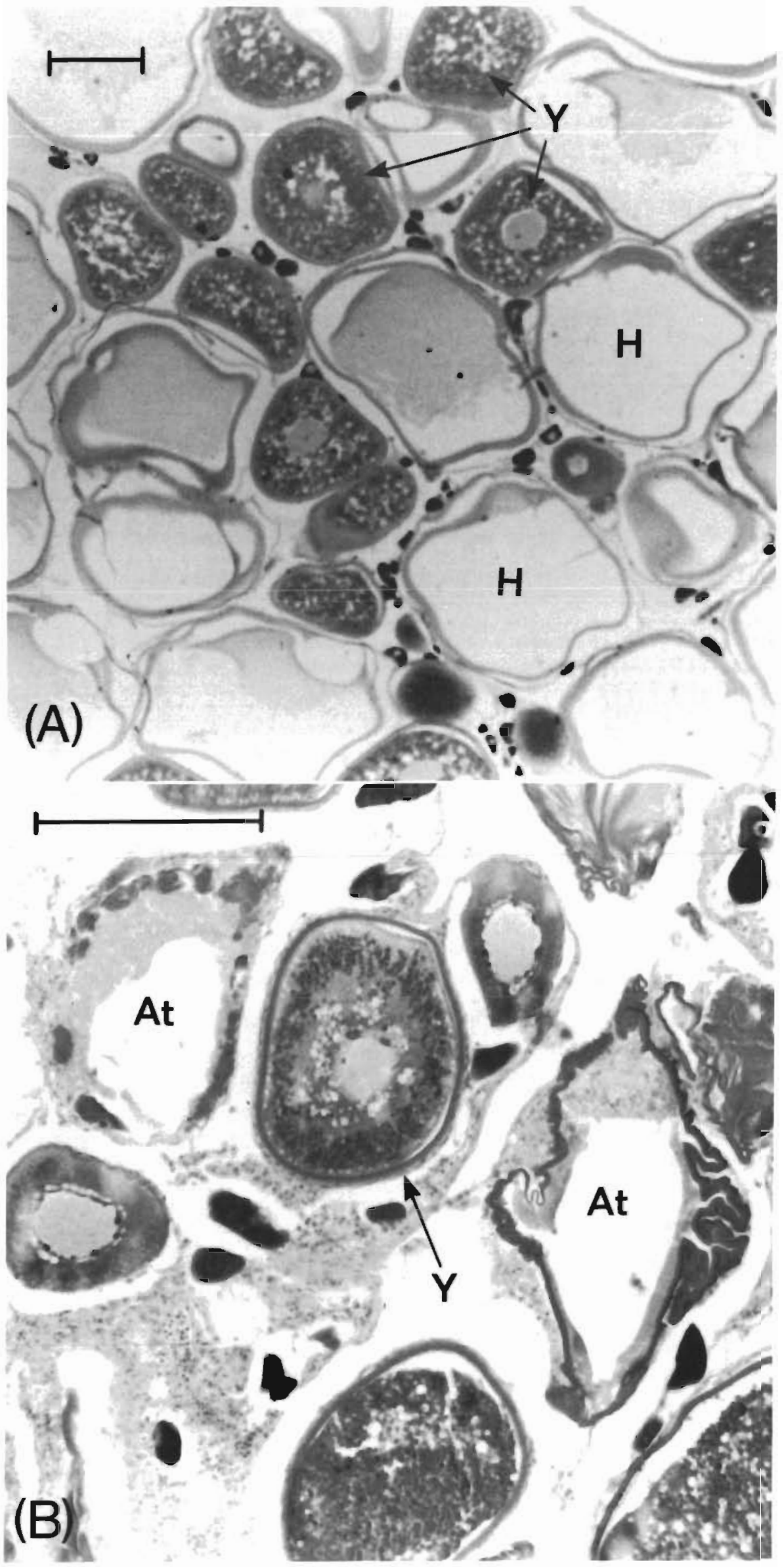

Fig. 1. Acanthopagrus australis. Transverse section of ovary taken during July. (A) Migratory specimen of $230 \mathrm{~mm}$ fork length. (B) Nonmigratory specimen of $235 \mathrm{~mm}$ fork length. Y: yolk-stage oocyte; $\mathrm{H}$ : hyaline-stage oocyte; At: atretic oocyte. Scale bars $300 \mu \mathrm{m}$ 
approximately half of the adult population does not participate in the annual spawning migration (Pollock, 1982a), even though there are no physical barriers which prevent these fish from migrating. The nonmigratory adults remain in the estuarine feeding areas during the spawning period.

In the present study, yellowfin bream were collected from a non-spawning estuarine area within Moreton Bay, Australia, before, during and after the spawning period. Specimens were also collected from a surf-bar spawning area at the entrance to Moreton Bay during the spawning period. Gonad and oocyte development, changes in nutritional state and sex ratios within age classes are compared between migratory and nonmigratory groups of yellowfin bream.

\section{MATERIALS AND METHODS}

Yellowfin bream were sampled each month from Moreton Bay, Australia $\left(27^{\circ} \mathrm{S}, 153^{\circ} \mathrm{E}\right)$ by stake netting at night. The net, approximately $400 \mathrm{~m}$ long and of $8 \mathrm{~cm}$ mesh, was set on intertidal sand banks at high tide and specimens were removed from the net as the tide ebbed. A total of 438 fish were taken during the period April to October 1982 from a turbid, mangrovefringed area (Deception Bay) where yellowfin bream occur throughout the year. A total of 225 fish were taken during the period May to August 1982 from a surf-bar (Jumpinpin), where yellowfin bream spawn (Pollock, 1982a). The distance from Deception Bay to Jumpinpin is approximately $80 \mathrm{~km}$ (A map of this region is given by Pollock et al., 1983).

The following information was recorded for each fish sampled : fork length (to the nearest $5 \mathrm{~mm}$ ); total body weight and eviscerated body weight (both to the nearest $5 \mathrm{~g}$ ) and gonad weight, stomach contents weight and visceral fat weight (all to the nearest $0.1 \mathrm{~g}$ ). Specimens taken during the study were of 110 to $350 \mathrm{~mm}$ fork length and included all age classes (Pollock, 1982b). Each fish collected during the spawning period (May to Aug) was classified as juvenile, male or female by examining the gonads macroscopically. This classification was not possible during the pre- and postspawning periods (i.e. Mar to Apr and Sep to Oct). Scale and otolith ageing techniques are not reliable methods for ageing yellowfin bream from Moreton Bay (Pollock, 1982b). However, length-frequency histograms contain modes corresponding with the first 2 or 3 age classes. From the von Bertalanffy growth equation for the yellowfin bream population in Moreton Bay (Pollock, 1982b), the lengths of fish in each age class during the period May to August were calculated: 0class, less than $170 \mathrm{~mm}$; I-class, from 170 to $215 \mathrm{~mm}$; IIclass, from 220 to $245 \mathrm{~mm}$; and III-class and older fish, greater than $245 \mathrm{~mm}$. Each fish collected from May to August was assigned an age according to its fork length.

Gonosmatic index and 3 indices of nutritional state (Jangaard et al., 1967; Pollard, 1972; Htun-Han, 1978b) were calculated for each fish:

$$
\text { Gonosomatic index }(\text { GSI })=\frac{\text { gonad weight }(g)}{\text { total body weight }(g)} \times 100
$$

Feeding index $(\mathrm{Fl})=\frac{\text { stomach contents weight }(\mathrm{g})}{\text { total body weight }(\mathrm{g})} \times 100$

Visceral fat index $(\mathrm{VFI})=\frac{\text { visceral fat weight }(\mathrm{g})}{\text { total body weight }(\mathrm{g})} \times 100$

Condition factor $(\mathrm{CF})=\frac{\text { eviscerated body weight }(\mathrm{g})}{[\text { fork length }(\mathrm{mm})]^{3}} \times 10^{5}$

where GSI = measure of gonad size in relation to body size; FI $=$ measure of feeding activity of the fish; $\mathrm{VFI}=$ accumulation of visceral fat relative to body size; $\mathrm{CF}=$ measure of 'robustness' of the eviscerated carcass. The denominator used in calculating CF eliminates the possibility of bias due to the weights of stomach contents and gonads.

Ovaries of 56 fish, subsampled randomly during May to August, were fixed in alcoholic Bouin's solution

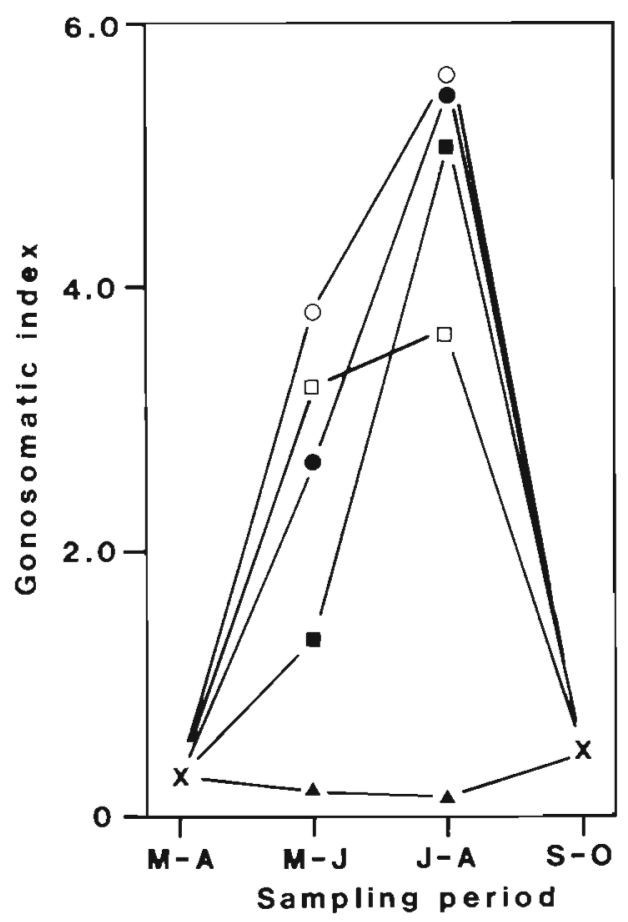

Fig. 2. Acanthopagrus australis. Mean gonosomatic index of fish taken before, during and after spawning period. $\square$ males and, $O$ females taken at a surf-bar spawning area (migratory fish); $\Delta$ juveniles; - males; $\bullet$ females and $x$ fish of undetermined sex, taken at a turbid, mangrove-fringed estuary (nonmigratory fish) 


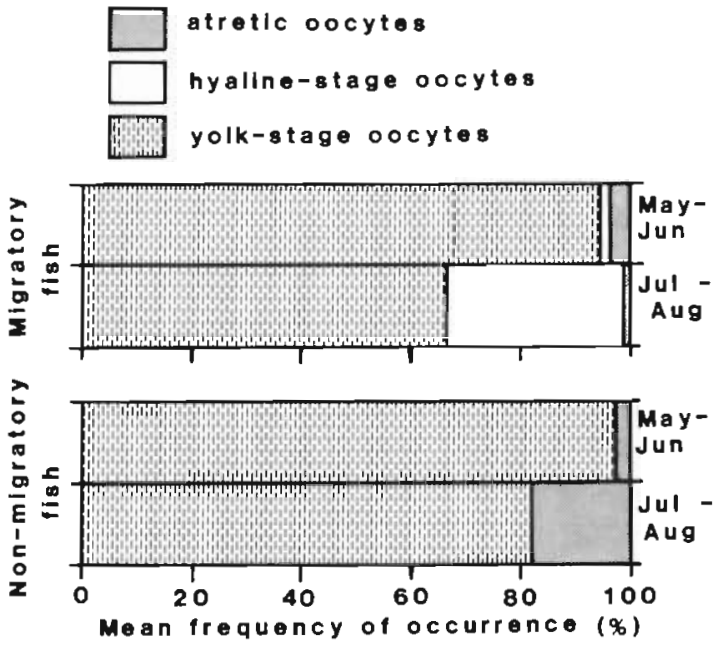

Fig. 3. Acanthopagrus australis. Mean frequency of occurrence of yolk-stage, hyaline-stage and atretic oocytes in the ovaries of migratory and non-migratory fish taken during spawning period

(Pantin, 1959) for 2 to $3 \mathrm{~d}$, and then stored in $70 \%$ alcohol solution. The mid-region of an ovary from each fish was later embedded in paraffin wax. Transverse sections were taken at $8 \mu \mathrm{m}$ and stained with haematoxylin and eosin. The numbers of yolk-stage, hyaline-stage, and atretic oocytes (Fig. 1) in a transverse section of the ovary were recorded and the percentage occurrence of each oocyte type calculated for each fish.

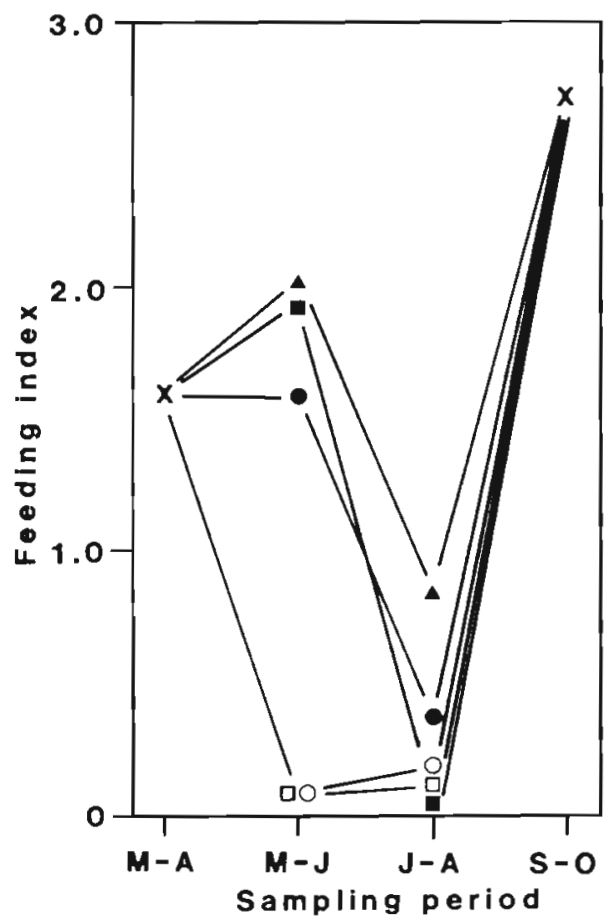

Fig. 4. Acanthopagrus australis. Mean feeding index of fish taken before, during and after spawning period. Symbols as in Fig. 2

\section{RESULTS}

\section{Gonad and oocyte development}

Gonosomatic index (GSI) of adult male and female yellowfin bream followed a similar pattern in both migratory and non-migratory groups. GSI increased from March to April, reached a peak in July to August, then decreased rapidly in September to October (Fig. 2). During the same period (Mar to Oct), GSI values of juvenile fish remained low. In the spawning period (May to Aug), yolk-stage oocytes were common in both migratory and non-migratory females (Fig. 3). However hyaline-stage oocytes only occurred in mi-

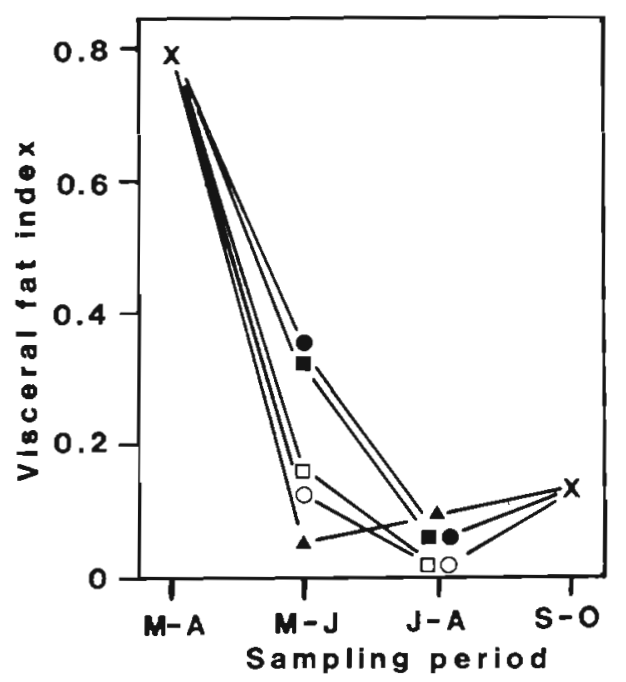

Fig. 5. Acanthopagrus australis. Mean visceral fat index of fish taken before, during and after spawning period. Symbols as in Fig. 2

gratory females and were significantly more common during July to August (Chi-square test, $\mathrm{p}<0.001$ ). Atretic oocytes were present in both migratory and non-migratory groups (Fig. 3), but they appear to be most common in the latter group during the late spawning period (Jul-Aug). The frequency of atretic oocytes differs significantly in the 4 sub-groups in Fig. 3 (Chi-square test, $\mathrm{p}<0.001$ ).

\section{Nutritional cycles}

Feeding index (FI) was relatively large before the spawning period (Fig. 4). During the early spawning period (May to Jun), FI remained relatively high in all non-migratory fish (males, females, juveniles). FI was relatively low during the early spawning period in all migratory fish (i.e. males, females; no juveniles were captured in the spawning area). FI was relatively low 


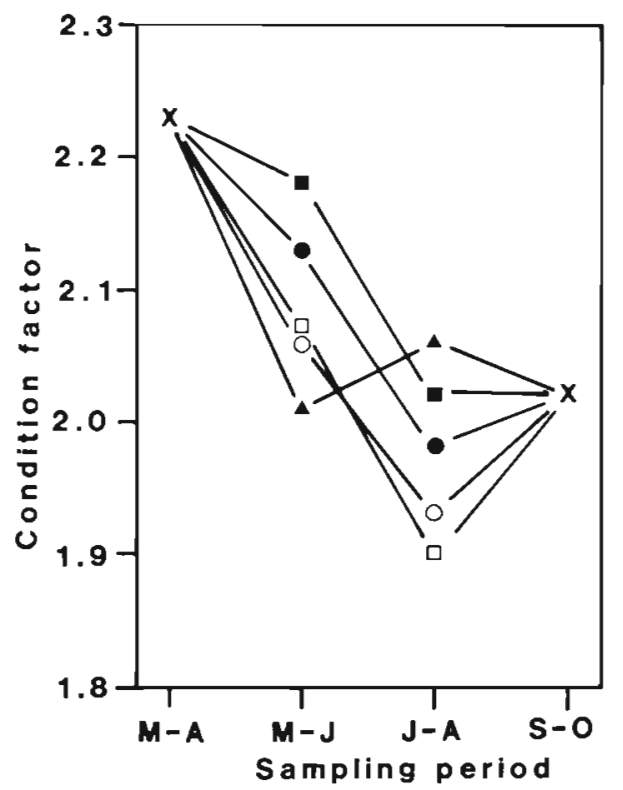

Fig. 6. Acanthopagrus australis. Mean condition factor of fish taken before, during and after spawning period. Symbols as in Fig. 2

for all adults during the late spawning period (Jul to Aug); it also decreased in juvenile fish during the period, but not to the same extent. After the spawning period (Sep to Oct), FI reached its highest value (Fig. 4). Visceral fat index (VFI) was highest before the spawning period, but decreased rapidly during the spawning period in both migratory and non-migratory fish (Fig. 5). The decrease in VFI was more rapid in migratory adults than non-migratory adults. Seasonal changes in condition factor ( $\mathrm{CF}$ ) were similar to those in VFI (Fig. 6). CF was highest before the spawning period and decreased in both migratory and non-migratory groups during the spawning period. However the decrease in CF was greatest in migratory fish (Fig. 6).

\section{Sex ratios within age classes}

During the spawning period, juveniles only occurred in the non-spawning area (Fig. 7). Juvenile fish were common in age classes 0 and I, but did not occur after age class II (Fig. 7). Within the migratory group, the proportion of females to males increases with age (Fig. 7). In the oldest age group (III-class and older), approximately $45 \%$ of the fish were female. Within the non-migratory group, the percentage of females increased rapidly with age and in the oldest age group all fish were female (Fig. 7). The II-class, non-migratory group contained a predominance of females $(65 \%)$; remaining fish in this age class included males and juveniles.

\section{DISCUSSION}

Yolk-stage oocytes represent an advanced stage of oogenesis. Such oocytes may either develop to the hyaline-stage, the last developmental stage before shedding, or become atretic and be resorbed (Smith and Young, 1966; Volodin et al., 1974; Htun-Han, 1978a). The results show that successful reproduction, as indicated by the presence of hyaline-stage oocytes, only occurs in yellowfin bream which participate in the annual spawning migration and arrive at the surf-bar. The oocytes of non-migratory yellowfin bream reach the yolk-stage, but then become atretic and are resorbed. In other teleosts, resorption of maturing oocytes has been recorded in cases where suitable spawning conditions are not available (Abraham, 1963; Kukuradze, 1968). The gonads of migratory and non-migratory adult yellowfin bream reach a similar size at the peak of the spawning period. The resorption of developing gametes by non-migratory individuals represents a considerable energy saving in the form of lipids and proteins which would otherwise be lost during spawning. It is interesting that oocyte development proceeds so far in non-migratory yellowfin bream prior to atresia. Considering the energetic costs involved, it is expected that selection would not favour

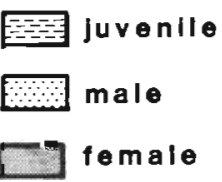

migratory fish

non-migratory flsh

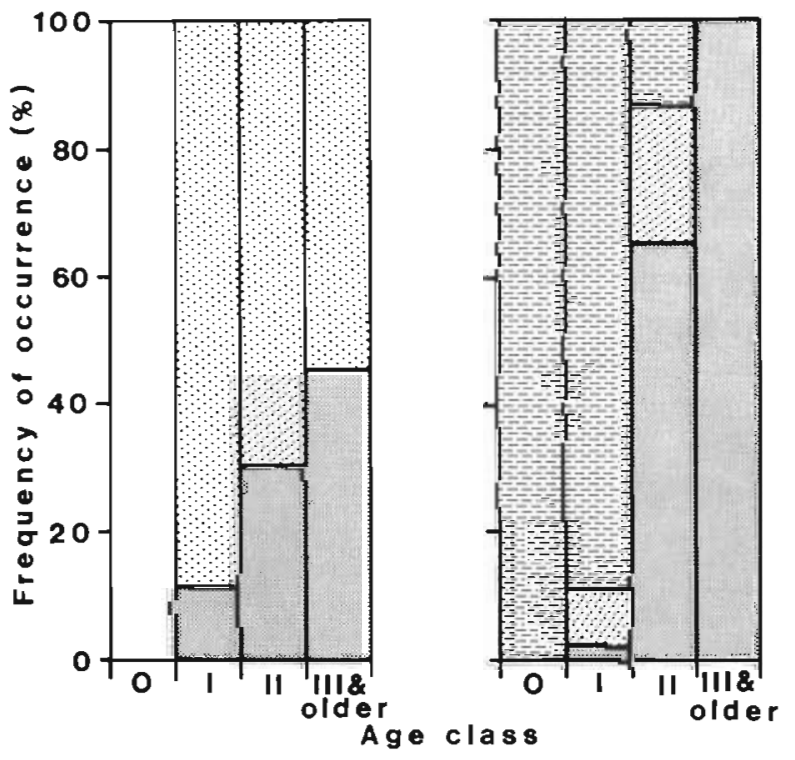

Fig. 7. Acanthopagrus australis. Percentage occurtence of juveniles, males and females by age; based on samples of 225 migratory fish and 165 non-migratory fish 
this strategy. Perhaps the final cue for participation or non-participation in the spawning migration occurs at a very late stage in the reproductive period (e.g. late Apr).

Reproduction in highly fecund fishes such as yellowfin bream (Munro, 1944) requires considerable energy (Bagenal, 1957; Wood, 1958; Love, 1970). Stored energy reserves are used in seasonally reproducing fishes to produce gametes (Hickling, 1945; Pollard, 1972). In the case of species which undergo annual spawning migrations, energy is required for gamete production and also for large-scale movements associated with these migrations. Bertin (1958) recognises 2 main types of fish with reference to the mobilization of energy reserves for reproduction: the 'lean fishes' in which lipids are stored in the liver, and the 'fat fishes' (such as yellowfin bream) in which fat is stored subcutaneously in the mesenteries and in the musculature. It is possible that, in migratory species, participation in the annual spawning migration is determined by the amount of stored energy reserves in individual fish. According to Golovanenko et al. (1970) pike-perch with the greatest stored energy reserves have the greatest spawning success. In the case of yellowfin bream, adult fish have a much higher condition factor (CF) and visceral fat index (VFI) than juveniles at the start of the spawning period. The mean distance of the spawning migration by yellowfin bream in Moreton Bay is about 50 to $60 \mathrm{~km}$ (Pollock, 1982a); the energetic costs involved are unknown at this stage. However both CF and VFI were much lower in migratory adults during the early spawning period. CF and VFI would be expected to be higher in migratory adults during the prespawning period if stored energy reserves were an important determinant of participation in the annual spawning migration. Unfortunately, it was not possible to determine CF and VFI of migratory and non-migratory adults before migration occurred.

The present study shows that in yellowfin bream, VFI and CF of migratory and non-migratory adults decrease with increasing GSI. However the decrease is more rapid in migratory fish, possibly because additional energy is required for migration. In addition non-migratory fish continue to feed during the early spawning period, whereas migratory fish do not feed in the spawning areas. It is interesting that spawning yellowfin bream at surf-bars in Moreton Bay are the subject of large angling fisheries (Pollock and Williams, 1983). These fish are capable of feeding because they are captured in large numbers on baited lines by anglers. Surf-bar spawning areas consist of sand banks and channels devoid of benthic plants and animals which yellowfin bream use as food (Dredge, 1976). Non-migratory yellowfin bream feed little during the late spawning period, even though these fish inhabit areas where food is available. The highest rate of oocyte resorption by non-migratory adults occurs at this time; therefore non-migratory adults possibly have no need to feed during the late spawning period due to the abundance of lipids and proteins resorbed from the gonads. After the spawning period, the feeding index is very large in all fish and VFI and CF begin to increase from the annual minimum values. At this time adult fish that had migrated to the spawning areas had rejoined the non-migratory fish in the estuarine feeding areas (Pollock, 1982a).

The results indicate differences in sex ratios within age classes between migratory and non-migratory groups. All 0-class fish were juvenile (immature) and did not participate in the spawning migration. All juvenile fish of classes I and II also did not participate in the spawning migration. The interpretation of sex ratio changes after age class 0 is made difficult for two reasons. Firstly, information on the proportion of migratory to non-migratory fish in each age class is not available. Secondly, protandrous sex inversion occurs in yellowfin bream (Pollock, in press) and this may account for the fact that the proportion of non-migratory females increases with age (Fig. 7). The agerelated increase in the proportion of non-migratory females was more rapid than that of migratory females, indicating a decreasing tendency of female fish to participate in the spawning migration with age. The proportion of migratory males in each age class decreases with age. This is probably due to protandrous sex inversion because no males older than age II were collected in the non-spawning area during the spawning period. In other words all male fish older than age II participate in the spawning migration. In addition to sex inversion, it is possible that differential mortality contributes to the preponderance of females in the older age classes.

The relations between migration, reproduction and nutrition in teleosts appear complicated. In particular, little attention has been given to the phenomenon of non-migration in populations which have annual spawning migrations. Although it was not possible to determine the fraction of the population which does not undertake the spawning migration, previous work (Pollock, 1982a) indicates that the fraction may be large (approximately half in the case of yellowfin bream). The presence of this phenomenon within a species is of interest both from a theoretical, ecological viewpoint as well as that of fisheries management. Further studies are necessary to determine the extent and significance of this phenomenon in teleost fishes.

Acknowledgements. I thank Messrs Dan Mayer, Rick Morton and Peter Stephens for valuable field and laboratory assistance. I am grateful to Drs John Beumer and Kevin Warburton for helpful comments during preparation of the manuscript. 


\section{LITERATURE CITED}

Abraham, B. (1963). A study of the oogenesis and egg resorption in the mullets Mugil cephalus and Mugil capito in Israel. In: General Fisheries Council for the Mediterranean, 7th Session, Madrid, March 1963. FAO, Fisheries Division, p. 435-453

Bagenal, T. B. (1957). The breeding and fecundity of the long rough dab Hippoglossoides platessoides (Fabr.) and the associated cycle in condition. J. mar. biol. Ass. U.K. 36: 339-375

Bertin, L. (1958). Sexualité et fecondation. In: Grasse, P. (ed.) Traite de Zoologie, Vol. XIII, No. 2, Masson, Paris, p. $1584-1652$

Blaber, S. J. M., Blaber, T. G. (1980). Factors affecting the distribution of juvenile estuarine and inshore fish. J. Fish Biol. 17: 143-162

Day, J. H., Blaber, S. J. M., Wallace, J. H. (1981). Estuarine fishes. In: Day, J. H. (ed.) Estuarine ecology with particular reference to southern Africa. Balkema, Cape Town, p. $197-221$

Dredge, M. C. L. (1976). Aspects of the ecology of three estuarine dwelling fish in south east Queensland. M. Sc. thesis, University of Queensland

Golovanenko, L. F., Shuvatova, T. F., Putina, Ye. P., Fedorova, L. S., Arakelova, A. L. (1970). A physiological and biochemical description of Don pikeperch females at different stages of the sexual cycle. Vop. Ikhtiol. 10: 260-267

Greene, C. W. (1926). The physiology of the spawning migration. Physiol. Rev. 6: 201-241

Harden Jones, F. R. (1968). Fish migration. Arnold, London

Hickling, C. F. (1945). The seasonal cycle of the Cornish pilchard, Sardina pilchardus Walbaum. J. mar. biol. Ass U.K. 26: $115-138$

Htun-Han, M. (1978a). The reproductive biology of the dab Limanda limanda (L.) in the North Sea: seasonal changes in the ovary. J. Fish Biol. 13: 351-359

Htun-Han, M. (1978b). The reproductive biology of the dab Limanda limanda (L.) in the North Sea: gonosomatic index, hepatosomatic index and condition factor. J. Fish Biol. 13: 369-378

Idler, D. R., Clemens, W. A. (1959). The energy expenditures of Fraser River sockeye salmon during the spawning migration to Chilko and Stuart Lakes. International Pacific Salmon Fisheries Commission Progress Report 6: 1-80

Jangaard, P. M., Brockerhoff, H., Burgher, R. D., Hoyle, R. J. (1967). Seasonal changes in general condition and lipid content of cod from inshore waters. J. Fish. Res. Bd Can. 24: $607-612$

Kukuradze, A. M. (1968). Effect of ecological conditions in the spawning period on the sexual cycle of the pikeperch Lucioperca lucioperca (L.) in the Kiliya delta of the Danube. Vop. Ikhtiol. 8: 463-466
Leggett, W. C., Trump, C. L. (1978). Energetics of migration in American shad. In: Schmidt-Koenig, K., Keeton, W. T. (ed.) Animal migration, navigation, and homing Springer-Verlag, Berlin, p. 370-377

Love, R. M. (1970). The chemical biology of fishes, Academic Piess, London

Moore, R., Reynolds, L. F. (1982). Migration patterns of barramundi, Lates calcarifer (Bloch), in Papua New Guinea. Aust. J. mar. Freshwat. Res. 33: 671-682

Pantin, C. F. A. (1959). Notes on microscopic technique for zoologists. Cambridge University Press, Cambridge

Munro, I. R. S. (1944). The economic biology of the Australian black bream Roughleyia australis (Gunther). M. Sc. thesis, University of Queensland

Pollard, D. A. (1972). The biology of a landlocked form of the normally catadromous salmoniform fish Galaxias maculatus (Jenyns). IV. Nutritional cycle. Aust. J. mar. Freshwat. Res. 23: 17-38

Pollock, B. R. (1982a). Movements and migrations of yellowfin bream, Acanthopagrus australis (Gunther), in Moreton Bay, Queensland as determined by tag recoveries. J. Fish Biol. 20: 245-252

Pollock, B. R. (1982b). Spawning period and growth of yellowfin bream, Acanthopagrus australis (Gunther), in Moreton Bay, Australia. J. Fish Biol. 21: 349-355

Pollock, B. R. (in press). The reproductive cycle of yellowfin bream, Acanthopagrus australis (Gunther), with particular reference to protandrous sex inversion. J. Fish Biol.

Pollock, B. R., Williams, M. J. (1983). An assessment of the angling fishery for yellowfin bream, Acanthopagrus australis (Gunther), in Moreton Bay, Australia. J. Fish Biol. 22: 125-132

Pollock, B. R., Weng, H., Morton, R. M. (1983). The seasonal occurrence of postlarval stages of yellowfin bream, Acanthopagrus australis (Gunther), and some factors affecting their movement into an estuary. J. Fish Biol. 22: 409-415

Smith, C. L., Young, P. H. (1966). Gonad structure and the reproductive cycle of the kelp bass, Paralabrax clathratus (Girard), with comments on the relationships of the serranid genus Paralabrax. Calif. Fish Game 52: 283-292

Thomson, J. M. (1955). The movements and migrations of mullet (Mugil cephalus L.). Aust. J. mar. Freshwat. Res. 6: 328-347

Volodin, V. M., Mezhnin, F. I., Kuz'mina, V. V. (1974). An experimental study of egg resorption in the bream (Abramis brama). Vop. Ikhtiol. 14: 219-231

Wallace, J. H. (1975). The estuarine fishes of the east coast of South Africa. I: Species composition and length distribution in the estuarine and marine environments. II: Seasonal abundance and migrations. Invest. Rep. Oceanog. Res. Inst., Durban 40: 1-72

Wood, R. J. (1958). Fat cycles in North Sea herring. J. Cons. perm. int. Explor. Mer 23: 390-398

This paper was submitted to the editor; it was accepted for printing on May 15, 1984 